\title{
The concept of Samogitianness in the Northern Samogitian dialect
}

\section{Žemaitiskuma koncepts ziemeḷu žemaišu dialektā}

\author{
Gintarẻ Judžentytė-Šinkūnienė, Saulė Nikartaitė \\ Institute of Applied Linguistics \\ Faculty of Philology, Vilnius University \\ Universiteto St. 5, LT-01513, Vilnius, Lithuania \\ E-mail: gintare.judzentyte@flf.vu.lt, saule.nikartaite@flf.stud.vu.lt
}

This paper explores semantics and cognitive meaning of concept of Samogitianness in Northern Samogitian dialect. The analysis verifies whether the meaning depends on the distribution within the territory (Samogitia and Aukštaitija), as well. The data for the research was collected by filling in the questionnaires and by recording audio material: Northern Samogitians were surveyed verbally and in written form (the ones who were surveyed verbally were speaking Samogitian, some questionnaires were also filled in Samogitian). The people representing other dialects were surveyed online on www.manoapklausa.lt. The interviewees were asked to answer the given questions without additional thinking. Three separate tables (key signs of Samogitianness for Samogitians; key signs of Samogitianness for non-Samogitians and common one (i. e., cognitive meaning of Samogitian in Lithuanian)) were completed to represent researched data. Cognitive meanings were compared, and actual differences were explained. The main aim of the paper is to reveal the cognitive meanings assigned to the concept of Samogitianness of Northern Samogitians, and representatives of other dialects, and to determine the prototype features of the concept of Samogitian.

Keywords: cognitive semantics; cognitive meaning; attribute; prototype; concept of Samogitianness.

\section{Introduction}

Although issues of the history and present of Samogitian self-consciousness and identity have lately received increasing attention (cf. Bliumas 1997; Pakalniškis 2001; Kalnius 2007a, 2007b; Nakienė 2007; Papaurèlytė, Župerka 2010; Kulevičius 2012; Petreikis 2012; Rutkovska, Bogdzevič, 2016; Pabrèža 2017, 31-36; Pajèdienè 2019), the notion of Samogitianness itself and the perception of Samogitianness, or, more precisely, the concept of Samogitianness, have not been fully studied in Lithuanian linguistics. Only a few of the studies focus on the concept of Samogitianness in terms of cognitive semantics.

The article of Rutkovska and Bogdzevič (2016) "Kognitywny obraz Żmudzina w języku polskim i litewskim" ("The Cognitive Picture of a Samogitian in Lithuanian and Polish") compare attitudes of two culturally and linguistically different nations (Lithuanian and Polish) to Samogitia and Samogitians. The concept of Samogitians is analysed not only from contemporary, but also from historical perspective. The article aims to reveal the Lithuanian and Polish attitudes towards Samogitians, to compare them and to establish the perception of 
Samogitians in the studied languages, i. e., whether it is rather similar or different. The authors base the analysis on the methodology of Jerzy Bartmiński, the initiator of Polish cognitive ethnolinguistics, lexicographic and textual data, as well as a survey. The survey revealed that the attitude of the Polish and Lithuanians towards Samogitians is quite similar: both the Polish and Lithuanian sources depict Samogitia as noble, patriotic, and faithful to traditions. At the end of the article, the authors provide a cognitive picture of Samogitians whose main features are national traits and character (Rutkovska, Bogdzevič 2016, 130).

Pajèdienè's (2019) article "Žemaitiškos tapatybès raiška: dèlione iš Kretingos tarmés žodyno (2011) pavyzdžių" ("The expression of Samogitian identity: a puzzle from the examples of the Kretinga dialect dictionary (2011)") explores the ways how Samogitians express their attitudes towards themselves and others in their speech. Based on examples from the Kretinga dialect dictionary, the author discusses the most prominent speech models by which people who speak in the Northern Samogitian Kretinga dialect reveal their attitude towards themselves and their environment (Pajediene 2019, 73). The article assumes that the classification of all models of utterances provoked by certain everyday situations found in the Kretinga dialect dictionary can provide a certain picture of the speaker.

The small number of the presented cognitive studies substantiates the view that Samogitianness and its perception remain a very scarcely researched and still relevant topic.

This article, based on the prototype theory, aims to analyse and discuss Samogitianness with the focus on defining the boundaries of the concept of Samogitianness, i. e., to identify the prototypical attributes of Samogitianness and describe the so-called prototypical Samogitian; and to find out which attributes characterizing the concept of Samogitianness are peripheral and can belong to other concepts. As the perception of a concept may differ within one areal (Maumevičienè $2010,17)$, the analysis attempts to determine how Samogitians themselves perceive Samogitianness, and what it means to Aukštaitians. Consequently, the object of this study is the concept of Samogitianness as existing in the consciousness of Samogitians (specifically Northern Samogitians) and Aukštaitians as a result of human experience.

The following objectives were set for implementation of the research: 1) to analyse the collected material which represents the Northern Samogitian subdialect and the Aukštaitian dialect; 2) to select empirical data which reflects the concept of Samogitianness and to discuss the respondents' substantiated and unsubstantiated attributes; 3) to identify prototypical and peripheral meanings; 4) to compare expression of the concept of Samogitianness in the Samogitian subdialect of Skuodas and in the Aukštaitian dialect.

The article consists of a theoretical part, which introduces the prototype theory used in the research, and a description of the data and research methods. The research is divided into two parts. The first part presents the perception of Samogitianness in the Samogitian sub-dialect of Skuodas, whereas the second part focuses on the expression of Samogitianness and its perception in the Aukštaitian dialect. Next, differences and similarities are established. Finally, the article provides conclusions and a list of references. 


\section{Theoretical background}

Cognitive linguistics originated in the 1970s in response to structural semantics that was dominant at the time. The latter, which largely viewed language as a closed system of signs, was replaced by another - the view of language as a kind of mental structure or percept (Allan 2009, 73). The main assumption of cognitive linguistics is that the content of language cannot be separated from the content of thinking because meaning is related to various forms of cognition, especially thinking (Harris 2006, 1). Prototype theory originated from Gestalt psychology, which is based on a holistic understanding of the world, in other words, that human beings unconsciously link perceived objects to certain groups and fill them in with the missing objects. Linking can be done by adding missing parts, grouping similar items, assigning certain items to others and the like (Maumevičienè 2010, 13). Representatives of cognitive linguistics adopted this view and applied it in prototype theory. The beginning of this theory is 1970 and the pioneer of prototype theory is Eleanor Rosch. Rosch (1975) analysed how one perceives focal colours. At the time, categorization in psychology received much attention. Rosch raised a hypothesis that some colours are more salient than others and that focal colours are codified in a simpler way and are easier to remember than less salient colours. Her study confirmed the hypothesis that focal colours are easier to recognize than less salient colours (Rosch 1975, 196). It was established that perception of focal colours does not dependent on the language but depends on human thinking, whereas perception of focal colours is almost the same for all people. Identification of focal colours is dependent on colour salience, which affects human vision more intensely. The results of the study led to broadening of the concept of focal colours and introduction of the term 'prototype' instead. The essence of prototype theory is division of the world into certain groups called categories that are best represented by prototypes (Maumevičienè 2010, 13). Each category is perceived as a single structure of knowledge, whereas a prototype is viewed as a mental reflection of the essential features of a category or as the most characteristic (the best and most typical) member of the category. Perception of a prototype depends on the situation (interaction between the object and the world), context (interaction between categories), cognitive models (the totality of experiences stored in human memory, including all knowledge in a particular field), and cultural models (specific to a particular nation or culture and demonstrating the ethnic nature of prototypes). Often one concept overlaps with another concept, i. e. the periphery of the concept goes beyond the boundaries of other concepts to form common, overlapping zones; thus, it can be argued that peripheral attributes in particular (and sometimes even central ones) can be easily assigned to another concept, they can fall within the boundaries of another concept or even category. Peripheral members of the concept belong to a category only as far as they resemble the prototype itself, i. e. they are like a prototype in at least one aspect and share at least one of the required features. Prototype theory was applied to analyse concepts of 'fruit', 'vehicle', 'furniture' (Rosch 1975); 'aggression' (Lysak et al. 1989); 'lie' (Coleman \& Kay 1981); 'love', 'emotions' (Fehr, Russell, 1984; 1991), etc.

To analyse concepts Rosch performed a variety of experiments. The subjects in the first experiment were students and only native English speakers. 
209 respondents were interviewed. Respondents were given sheets of paper with the category name at the top of the sheet. Seven members of the category were listed below the category name and students had to group them from the best representing the category (No. 1) to the least (No. 7). For example, one member of the category 'fruit' is an apple; if you think it best represents the category, write 1, if least - write 7 , if partially - write 4 . Half of the respondents received the same randomized categories and their members, and the other half received different ones. The results showed that the respondents named the best member (prototype) very similarly. The respondents had the same opinion on the best member in 9 out of 10 categories and $95 \%$ of the respondent listed it as No. 1. The research revealed that prototypicality is gradual, in other words, category boundaries are uncertain (Rosch 1975, 197-199).

Some concepts are more specific than others, such as 'birds' - a crow, a stork, a sparrow, and so on. From the attributes listed, one can easily guess the concept as in the study conducted by Rosch on the concept of fruit. However, sometimes it is impossible to recognize the category because the meanings are very broad and belong to several concepts. For instance, the most prototypical member of the concept of Samogitianness such as 'stubbornness' can be applied not only to Samogitians, but also to the majority of Lithuanians or people of other nationalities, as it depends on the character of a particular human being. However, when respondents are asked to name the difference between Samogitians and Aukštaitians, the answer almost invariably is that Samogitians are stubborn.

\section{Material and methods}

The data for this research was collected by applying a cognitive survey approach (Uffelen et al. 2011, 2-3; Forcino et. al. 2016, 5-6). As our memory relies more on associations than on unrelated events, there are many ways to pull these associations out and see the whole picture. This method is used to obtain qualitative data and is also called a spontaneous language method, which allows to extract more information/details from the respondent and reveal secret thinking processes that are usually hidden. The focus is on the design of the questionnaire itself as it should target the aim of the study. Most often, cognitive interviews are conducted by using verbal techniques, such as think-aloud, to allow the researcher to understand the respondent's entire course of thinking and to see a broader picture of the responses. The interview is conducted face-to-face, enabling the researcher to answer the respondent's questions. If necessary, the researcher can clarify, supplement the questions, and explain the terminology, etc. Proponents of the method also analyse information obtained in the written form (Willis, Artino 2013, 335).

The focus in this research is on the concept of Samogitianness as existing in the consciousness of Northern Samogitians. Skuodas was purposefully selected for the study. The main reason - it is one of the most prototypical cities not just of Northern Samogitia, but also of the whole Samogitia (Merkytė-Švarcienè 2016, 139).

The discussed method was applied in the following way:

1. Two groups - Northern Samogitians/non-Samogitians - were selected and interviewed: representatives of Northern Samogitians were interviewed orally and in writing; non-Samogitians were interviewed solely in writing. 
2. The most important factor that determined the selection of Northern Samogitians was their origin and permanent living place. Residents of Skuodas filled in the questionnaire (see Appendix 1), some of them agreed to audio recording.

3. Audio recordings were made to collect more linguistic samples and supplement the number of attributes selected from questionnaires. Audio recording was chosen because human thinking is best reflected through conversation, because people speak spontaneously, without any preparation, and thus reveal their true thinking. The recordings are full of additional information, as people speak 'the real language', give examples, explain, deviate from the subject, and return to it. Recording was based on the unstructured interview method: the form of questioning is free, the situation is open and can change, and the most important task is to obtain as much information about the topic as possible (in this case, to get as many attributes of Samogitianness as possible) (Richards 2009, 185). The free association approach was also used when the interviewee spoke about Samogitianness and mentioned one or another word that helped to contextually hear another word related to the topic (Ingwersen, Nielsen 1999, 18).

4. The online survey form on www.manoapklausa.lt was adapted to nonSamogitians. Random Aukštaitians completed it (see Appendix 2). The non-Samogitians were added to the research to check the most prototypical attributes within the major Lithuanian dialects, as well as a material that helped to understand the way of Samogitian thinking.

151 respondents were interviewed in writing and 40 Northern Samogitian respondents completed oral interviews. 151 questionnaires and 2 hours $45 \mathrm{~min}$. of recordings were collected. Out of all collected questionnaires, 100 were filled in by Northern Samogitians and 51 were filled in by Aukštaitians.

All recorded and interviewed Samogitian respondents (aged from 16 to 78) were from Skuodas or Skuodas district. This district was chosen because of its geographical location - it is the furthest from the central part of Lithuania (Kaunas, Vilnius). Once again, people from Skuodas district are attributed to the North Samogitian Kretinga sub-dialect that is believed to best represent Samogitians (Kalnius 2012, 332). Respondents were interviewed both orally and in writing to perform both quantitative and qualitative analysis of the concept of Samogitianness. Besides, this allowed verifying the answers to the same questions both in the questionnaire and in the face-to-face interview, because the answers can be distorted due to lack of motivation or other reasons. The data obtained from the questionnaires and the interviews were well balanced and complemented each other. The information obtained from the questionnaires did not contradict the information obtained through interviews. Some proponents of the cognitive survey method say that additional interviews help to notice new issues or aspects, even though the frequency of new information decreases (Blair, Conrad 2011, 654).

Aukštaitian respondents (aged from 17 to 64) who completed online survey mostly represented Eastern and Western Aukštaitians: approximately equal number 
of respondents identified their place of residence in Marijampole (11), Utena (14), and Kaunas district (17). 9 respondents indicated Vilnius as their place of residence.

The collected material was analysed based on the prototype theory mentioned above: first, the respondents had to consider and answer the questions using their intuition. The Samogitians' questionnaires and voice recordings and the Aukštaitians' questionnaires were used to extract all the attributes of the concept Samogitianness (i.e., features that help to distinguish between the main and the secondary members of one category), which were counted and ranked by the frequency used (Fehr, Rusell 1991, 427; see Appendix 3, 4).

The attributes were collected, as follows: all the words that described Samogitianness or Samogitians were selected while reading or listening to the responses. For example, all answers to the questions mentioned more than one attribute; attributes were repeated and new ones added - Samogitians are strong not only physically but also mentally - in this type of answers, two attributes were distinguished ('strength' and 'common sense'). The attributes, which were repeated, were not counted as new ones. The most frequently repeated synonymous attribute was used to name the group, e.g., 'distinction': uniqueness, authenticity, individuality, peculiarity, originality, singularity, being different. This means that the word 'distinction' was mentioned most frequently, whereas other attributes - more seldom.

A prototype in this paper is understood as the most frequently mentioned attribute, thus, it is the central member, whereas the least frequently mentioned attribute is a peripheral member (Fehr, Russel 1991, 428). All other members are distributed between them. There is no clear boundary where the central members end and where the peripheral ones begin. Setting such a boundary is not at all possible. Attention was paid to the perception of Samogitianness as viewed by Samogitians and Aukštaitians respectively. In this way, the attributes of Samogitianness that prevail in these groups were established. The attributes identified by the different groups were compared. Thus, the attributes that dominate all over Lithuania were identified.

\section{The concept of Samogitianness in selected Lithuanian dialects}

The 10 most common attributes from each group (Norther Samogitian/ Aukštaitian) were selected for this study. As it was mentioned in section 3, the research focuses on the concept of Samogitianness as existing in the consciousness of Northern Samogitians. The Aukštaitian data was chosen to check the universality of attributes, to better understand Samogitian perception. In addition, when talking about Samogitianness, Samogitians often compare themselves with the Aukštaitians.

\subsection{The concept of Samogitianness as viewed by Northern Samogitians}

The most prototypical attribute of Samogitianness as viewed by Samogitians is stubbornness. It was named 81 times (more than a half of the respondents, Figure 1). 


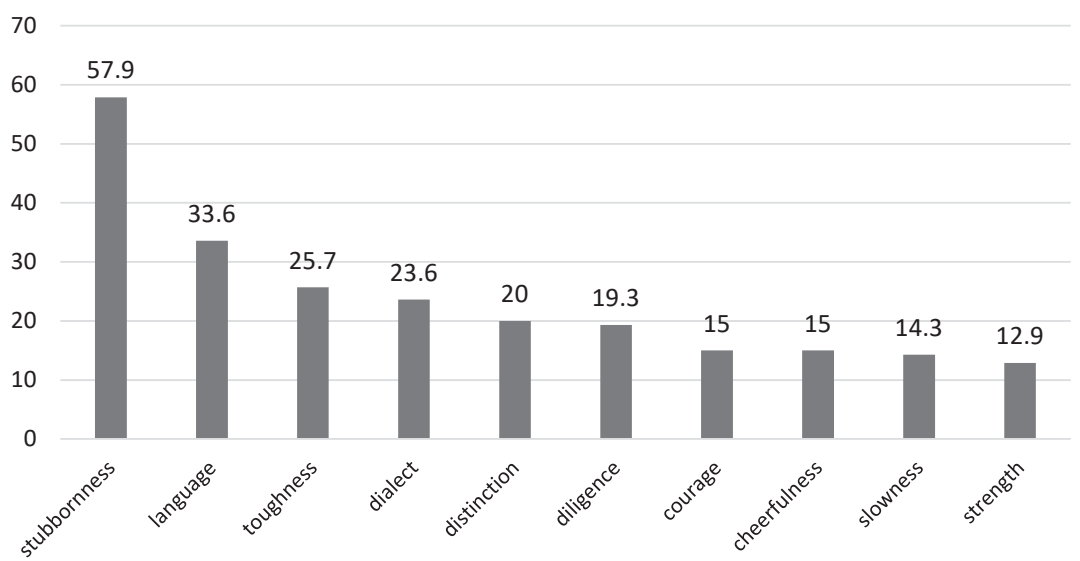

Figure 1. Ten attributes to describe Samogitianness as viewed by Samogitians (\%)

Some respondents who indicated this attribute also added that Samogitian stubbornness is an advantage, because Samogitians never give up when in trouble, and stated that Samogitians stubbornly pursue a goal, and specify that this type of stubbornness does not mean defending one's opinion blindly or standing firm against the principles. Samogitians are said to feel responsibility for their words. To support this statement the majority of the respondents provided a number of sayings, phraseologisms (1) and anecdotes (2):

(1) A stubborn Samogitian can push the clouds; as stubborn as a Samogitian.

(2) The devil put representatives of all dialects into separate bags. Suddenly a rooster crowed. The devil was frightened, threw his bags and fled. The Aukštaitian does not wait long to get out of the bag and runs away. Meanwhile, the Suduvite awaits next to the bag. The Samogitian says to him "What are you waiting for?" The Suduvite responds, "I am waiting for the Samogitian to get out of the bag to take the bag"; to which the Samogitian says, "The one who put me in will take me out".

Some respondents also mention historical facts, such as baptism of Samogitians, which happened much later than in other parts of Lithuania. Thus, from the point of view of Samogitians, Samogitianness is most associated with stubbornness. In some cases, the respondents did not name the exact attribute as 'stubbornness', but provided such statements as:

(3) I am like a goat; Samogitians pursue their goal to the end; It is difficult to change a Samogitian's mind; If a Samogitian comes up with something, he will do it.

It should be mentioned that stubbornness is not necessarily viewed as a character trait; some respondents indicated stubbornness simply because Samogitians always speak Samogitian everywhere.

The second and fourth most frequently repeated attributes were 'language' and 'dialect' respectfully. 'Language' was used 47 times and 'dialect' was mentioned 33 times. Often Samogitians subconsciously use the word 'language' instead of 'dialect', but sometimes they consciously emphasize that it is a language and not 
a dialect. This is because the Samogitian dialect is most distinct from the standard Lithuanian language and is incomprehensible to most speakers of other dialects. Some respondents named such attributes as 'respect for your language', 'native language'. They belong to the attribute 'language'. Respondents said that the aim of Samogitians is to cherish and preserve their language and claim that representatives of other dialects are not that interested in preserving their own dialect, unlike Samogitians. Interestingly, one respondent (though there was no such question in the questionnaire, so we do not know how many people like this there are) first learned to speak Samogitian and only then learned to speak the standard language at school. Samogitians say that it is easier for them to express their ideas in Samogitian than in the standard language. Perhaps therefore some respondents refer to the Samogitian dialect as their mother tongue:

(4) I feel responsibility to cherish, speak, and respect my mother tongue.

Several respondents named some Samogitian words that do not exist in the standard Lithuanian language, thus further highlighting the difference between Aukštaitians and Samogitians. One of the respondents from Skuodas says:

(5) What makes us different from representatives of other dialects, what makes us special is that nowhere else can you find such words as in the Samogitian language: 'be proto protingas' (mindlessly clever), 'dideliai mažas' (largely small), 'baisiai/žiauriai gražus' (terribly beautiful).

Some respondents claimed that Samogitians could easier communicate with people from foreign countries:

(6) Even when I was abroad, I spoke Samogitian, in Belgium, and I could communicate and was understood, and those who spoke the standard language were not understood.

A few respondents stated that when they strolled along Vilnius streets and spoke Samogitian, people looked at them as if they were foreigners:

(7) They did not understand our language.

One respondent told a joke that further emphasizes linguistic differences:

(8) An Aukštaitian and a Samogitian worked in the fields. The Aukštaitian saw the Samogitian carrying something heavy and asked, "How are you doing?", and the Samogitian replied, "Smagiai, smagiai" (literally: cheerfully, pleasantly). The Aukštaitian said, "Well, if that's pleasant, carry on." The respondent explained: 'Because in Samogitian 'smagiai' means 'hard'.

In addition, the respondents believe that the Samogitian dialect appeals to most Aukštaitians and that Samogitians are asked to speak as much as possible in Samogitian; they say that this evokes cheerful emotions. Some mention that Samogitians have the largest variety of sub-dialects.

The third most frequent attribute is 'toughness'. It was used 36 times. Most Samogitians used the word 'tough' to describe the character of Samogitians. Some used it to refer to appearance or built. This attribute also encompasses words that were used in the survey: strength, strong, hard character; firm in one's beliefs; determined (DLKŽ ${ }^{\mathrm{e}}$ a firm determination). The respondents provided examples to substantiate this attribute: 
(9) As strong as a Samogitian', Samogitians with strong character, as strong as a Samogitian horse, Samogitians are strong not only physically, but also mentally, Samogitians are firmly built, Samogitians are strong, they do not change their word, in other words they have determination.

Toughness and determination are revealed in the saying:

(10) Maurai ne maurai, mausim kiaurai (literally: Moors or not, we will spear them through).

Some claimed that Samogitian men are strong and women are gentle. Some respondents described toughness as a feature of appearance, e. g.:

(11) Samogitian men had to be well built because they fought a lot and celebrated many victories.

Simonas Daukantas' citation from his work "Būdas senovès lietuvių, kalnėnų ir žemaičių" ("The Ways of the Ancient Lithuanian Highlanders and Samogitians") reveals the following perception: "All were of a medium built, not small, but rather serious, and men with strong shoulders" (Daukantas 1845, cit. in Vanagienè 1993, 21). Firmness also belongs to this attribute as a synonym of toughness. Most respondents refer to firmness when talking about character, but there are also ambiguous cases, such as:

(12) Samogitians are tough men.

It is important to mention the attribute of 'distinction' and its synonyms uniqueness, authenticity, individuality, peculiarity, originality, singularity, being different. This attribute was mentioned 28 times. Firstly, Samogitians believe that uniqueness lies in their language, which representatives of other dialects often do not understand:

(13) For me being Samogitian is being distinct, because I speak the beautiful Samogitian language; To have something distinct, e.g. when talking to others about dialects we can show that we even text in Samogitian; We have a different alphabet.

Secondly, Samogitians believe that they are unique because they cherish their dialect, customs, traditions, they create, sing, and even have events in the Samogitian dialect and uphold it more stalwartly than the representatives of other dialects. Respondents emphasize that the municipal council of Skuodas district holds meetings in Samogitian. Interestingly, Samogitians often raise the Samogitian flag next to their houses, thus showing a close connection with the region and encouraging their neighbours and others not to be afraid to say that they are Samogitians. Samogitians claim that they are unique because of the history - they were baptized later than all the other parts of Lithuania and if not for the fighting efficiency and 'courage' of Samogitians (attribute was mentioned 21 times), Lithuania would probably not exist today. Edmundas Untulis, a resident of Skuodas, a director, playwright, prose writer and journalist says:

(14) Samogitians, as always, are the pathfinders of the whole Lithuania. When in the Battle of Grunwald it was necessary to fight, they came and won, when Latvians needed help in the Battle of Durbe to fight Germans dressed in the armour, they went and dealt with them. They lead everywhere, like a shining beacon. 
Some not only highlighted distinction but also encouraged it:

(15) This is why we are attractive and peculiar, which makes us distinct. If we all are the same, one mass, there will not be any distinction.

Respondents state that not only the Samogitian dialect (peculiar words), the character of Samogitians, but also their gait and posture are unique. It is said that you can recognize Samogitians even from their gait:

(16) Samogitians waddle when walking.

They are unique and distinct because:

(17) They are rigid, less flexible physically, as if stiff.

Interestingly, one respondent who used the word 'originality' had in mind the appearance of a Samogitian:

(18) Strictly beautiful, original Samogitian girls.

The sixth most frequent attribute is diligence, which was used 27 times. This attribute is somewhat related to the first one (stubbornness), because Samogitians claim that if Samogitians set their mind to do something, they always do it, if they start work, they always finish it. One respondent stated that Samogitians are very hard working:

(19) It is enough to have a look. When we were in Aukštaitia - oh, boy, how high their grass is, however, in Samogitia, just look at this.

This attribute also encompasses such word combinations as not afraid of physical work, ready to work. Besides, the respondents provided examples to visualize this attribute - as hard working as a Samogitian horse.

The eight most frequent attribute is 'cheerfulness', which was mentioned 21 times. This attribute also embraces such words and word combinations as funny, humorous, able to joke, merry fellows, with a good sense of humour, ones who know lots of jokes, e.g.:

(20) A Samogitian without jokes is like a pie without yeast.

Some say Samogitians are cheerful because there are many jokes and funny sayings in the Samogitian dialect.

Slowness was mentioned 20 times. Interestingly, some respondents used a borrowing from the Polish language spakainus ('calm'), which was used in the Samogitian dialect, but clarified the meaning of the word used in brackets. This attribute also includes such words as slow-footed, slow thinking, taking time, slow speed, thinking long before taking decision. There were two variants - slow and calm, some were not explained, did not have any context. They were attributed to slowness because in the online Dictionary of the Lithuanian Language (DLKŽ ${ }^{\mathrm{e}}$ ) its second meaning is 'of a slow nature', and the third is 'calm, without trouble' (the first meaning is 'immovable' thus unsuitable in this context). Respondents claim that Samogitians are slow and give the following examples:

(21) First Samogitians think and consider and only then say something; we look, measure, go round hundred times and only then cut. If Samogitians cut something - that's it, it's cut, they won't try to mend it back (here we can also see the attribute of stubbornness - they won't mend it, since they are stubborn); they think and think, but when they say something, it is ultimate; 
ì rèst neìginsi - you can't make them faster (here we have a kind of language barrier as it is impossible to translate this saying into Lithuanian, thus its meaning was interpreted by the author of the article).

Others state that:

(22) He is not slow, he is in deep thoughts.

One respondent said that she heard such a saying:

(23) You behave like a Samogitian living close to Latvia (i. e. you are slow).

Samogitians say they never talk without a purpose, and if they talk, they do it in a clear, accurate manner. Interestingly, slowness is a prototypical feature of Estonians, there is a saying: slow as an Estonian. However, as the survey shows, it is also attributed to Samogitians, or only a part of the nation. There were respondents who denied that Samogitians are slow:

(24) Samogitians are not slow, they are more relaxed, less stressed; we are fastwe keep up with modern technology - we are modern; Samogitians speak fast.

The attribute 'strength' was named 18 times. Samogitians used the word 'strength' not as a character trait, but as a physical feature, thus it is to some extent synonymous with 'toughness'. Samogitians provide examples to explain this attribute:

(25) Samogitians are strong men - when they see something needs to be done, they just do it, they do not beat about the bush; they are strong and well built.

One respondent states that the real Samogitian looks like Vingiai Jonas from the Samogitian short story "Marti" by Žemaite (1896). The respondent did not comment further on what she believed Vingiai Jonas is like, so the quote was taken from the short story: "Full-figured, tall, with broadest shoulders, a protruding belly, slightly crooked, arms tarred like logs, legs crooked like bows, the mouth like a sower, the nose like a cucumber..." (Žemaite 1896, 2). Although attributes 'highness' and 'thinness' are not synonyms of strength, it is important to note that different Samogitians have a different image of a typical Samogitian. Even though the above-mentioned respondent stated that Samogitians are large and tall (there were more respondents who think so), another respondent stated that Samogitians are thin and tall, and added that Samogitians have a narrow chin. These examples show that when referring to words such as firmness, toughness, and strength, respondents might refer not only to character traits but also to physical features. Therefore, there is a certain degree of ambiguity. Firmness and toughness were attributed to character traits, whereas strength - to physical (though there are some word combinations as strong character (mentioned two times). Such a compound was included in the attribute 'toughness'. Most often, the following explanation was used to imply what feature (character or physical) the respondent had in mind when speaking, e.g. strong as an oak - uncompromising, has a strong opinionattributed to character traits, hence 'toughness'; why do I think that all Samogitians are dark-haired and strong? - attributed to physical features, hence 'strength'.

The attribute 'traditions' was mentioned 15 times, whereas 'customs' - 14. These two are not represented in Figure 1 as the focus is on the top ten attributes 
in the study. Yet in terms of dialects, the subject of traditions and customs is inseparable. Therefore, it was decided to make an exception in this case. Although the two attributes are quite synonymous, it was decided to distinguish between them, as respondents usually refer to traditions as the tradition of cherishing the Samogitian language, folklore, national costume, and in terms of customs they specify that those are dishes, thus, more abstractly, festive customs. This suggests that respondents perceive these two words differently. The attribute 'tradition' included the words tradition of language / dialect, observance of traditions, folklore, traditional clothes / clothing / costumes, while dishes, meals, exclusive customs, custom observance were attributed to 'custom'. Samogitian national clothes are distinguished by their colourfulness. Traditional Samogitian songs, music, dances, and dishes are also different from other regions of Lithuania. Most respondents say that it is very important to uphold traditions and customs. They not only speak about this, but also do it, as quite many provided such examples as:

(26) I am writing a paper on regional studies; I am writing about my family tree, my roots; I am the director of the Samogitian Theatre; We organize a Samogitian reading competition; I am a member of the Samogitian society; I have a Samogitian passport; I have put a Samogitian flag next to my house; I have a sticker with the coat of arms of Samogitia on my car.

Moreover, they like to preserve Samogitian traditions, way of life, and history based on true facts. Some claimed that Samogitian customs are very different from the Aukštaitian ones:

(27) I remember that when I was a kid, together with the family, we went to relatives in Suvalkija and they had a lot of food on the table, but we couldn't eat anything because the food looked unpalatable and I wondered how they could eat this.

Respondents also emphasized preservation and continuity of traditions and the need for Samogitians to teach their children to speak Samogitian:

(28) It is like a gift from parents to me and I hope to pass it on to my children.

Thus, the Samogitian respondents mentioned 109 attributes that describe Samogitianness. There are some attributes that contradict each other, e.g. slowness / velocity; calmness / cheerfulness; antiquity / modernity, and there are some synonyms, e.g. traditions and customs are commonly used as synonyms, other synonyms were included into an appropriate attribute. The cognitive meaning of Samogitianness to Samogitians is wide; however, the analysis of prototypical members would provide the following meaning: Samogitian is a language, but also a dialect that is most distinct from other dialects of Lithuania. Samogitians are characterized by stubbornness, diligence, and toughness.

\subsection{The concept of Samogitianness as viewed by Aukštaitians}

The most prototypical attribute of Samogitianness as viewed by nonSamogitians is stubbornness. It was mentioned 39 times (Figure 2): 


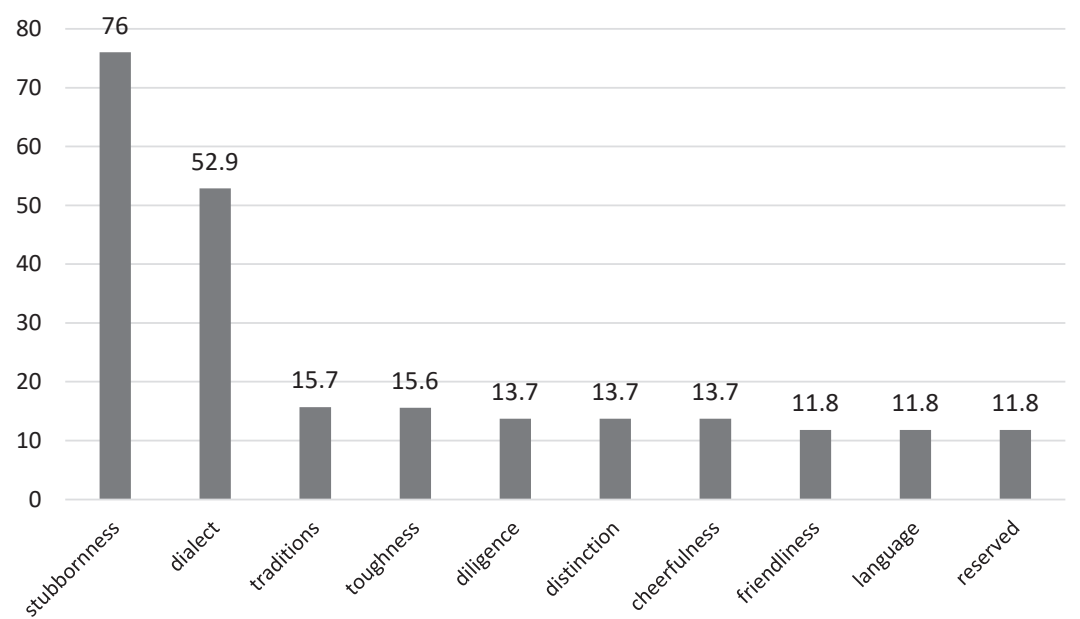

Figure 2. Ten attributes to describe Samogitianness as viewed by Aukštaitians (\%)

To substantiate this attribute, respondents provided some sayings:

(29) As stubborn as a Samogitian; A stubborn Samogitian can push the clouds.

Stubbornness is often related with the Samogitians' character as well as with the use of the Samogitian language at all times in all situations. Only one respondent claimed that Samogitians are as stubborn as Aukštaitians. Others refer to the Samogitian stubbornness as a synonym to adherence to beliefs:

(30) It is a person who never gives in, tries to prove his truth at all cost and does not recognize opinions of others.

Some respondents claimed that Samogitians are stubborn because they want everything to be done their own way:

(31) I find it very difficult to find a compromise with them because they extremely adhere to their beliefs; they are very stubborn, in the good sense of the word; endlessly stubborn and won't back down on an issue even if they are wrong.

These examples show that some respondents view stubbornness as a negative trait and others consider it to be a positive trait. Some say that Samogitians are reasonably stubborn, while others claim that they defend their views, even though they know they are wrong. Such differences in opinions occur because all Samogitians, like other people, are different and attributes can be only partially attributed, like beliefs or stereotypes. The attributes of Samogitianness are as if encoded in our minds and appear involuntarily. It does not take long to think of the typical features of Samogitians, and both Samogitians and Aukštaitians answer this question in a very similar way, though we clearly understand that Samogitians do not differ from Aukštaitians (at least in character). Features attributed to a concept are highly subjective and depend on each person's individual life experience.

The second most frequent prototypical attribute is 'dialect', which was mentioned by representatives of other dialects 27 times. Some of the respondents think that Samogitians are most proud of and cherish their dialect. Most representatives of other dialects say that they do not understand the Samogitian dialect: 
(32) It is always very interesting to listen to Samogitians speak in their dialect and you think to yourself that it is kind of Lithuanian, but you cannot understand anything.

Others argue that Samogitians are very adaptable to the linguistic environment; they can speak both Samogitian and the standard language and can switch from the standard language to Samogitian and vice versa (without any hassle). They also claim that Samogitians do not have a strong accent when speaking the standard language and many people do not even understand that they talk to a Samogitian. As an example, they claim that it is easier to recognize representatives of Dzūkian and Suvalkian dialects by their pronunciation. Aukštaitians note that Samogitians are more dedicated to safeguarding their dialect than representatives of other dialects. Some respondents stated that Samogitians persistently speak in their dialect (even in the public discourse). Interestingly, some people think that in the public discourse one can only speak the standard language and they do not understand why Samogitians usually speak in their dialect. The response of many Samogitians to this would probably be that every resident of Lithuania should understand it, because Samogitians speak Lithuanian. Moreover, it is easier for Samogitians to express their thoughts in their dialect because they are so used to it. As mentioned earlier, Samogitians speak in their dialect not only at home, but also during events, shopping, even at school during the breaks, and pupils often speak Samogitian during classes. Interestingly, some respondents claimed that Samogitians are people who speak with a Samogitian accent. Such description seems to point to a distinct linguistic group, especially when most say they do not understand the Samogitian dialect. One respondent stated that the Samogitian dialect is interesting to him because it is the strangest of all dialects in Lithuania. Some respondents claimed that Samogitians feel superior over the representatives of other dialects:

(33) I have even met Samogitians who claim that their dialect is superior / more beautiful / more special than other dialects; Samogitians usually say 'tu' (pronoun 'you' used when talking familiarly) to strangers, pretend that they are better than other Lithuanians, they don't like other Samogitians who speak the standard language.

Interestingly, Samogitian respondents also mentioned a similar distinction, but Samogitians referred to it as being different rather than superior. Thus, it is possible to say that most Aukštaitians find it interesting to listen to people speaking Samogitian and they regard this attribute as very positive and inseparable from the whole Lithuania.

The third most frequent attribute is 'traditions'. It was mentioned 8 times. Respondents claim that Samogitians have different traditions but often do not name them:

\section{(34) It is a part of Lithuania with slightly different, specific traditions.}

Only the traditional Samogitian cuisine was mentioned, e. g. 'kastinys' (sour cream butter), 'kanapine' (toasted hemp seed spice), 'cibulyne' (herring and onion soup), as well as the oral tradition of the dialect. The majority of respondents say that Samogitians in comparison with all other dialects in Lithuania care about preserving and promoting their traditions. They argue that the Samogitian 
Lithuanianness is more traditional and that Samogitians cherish their traditions most compared to representatives of all other dialects. None of the respondents mentioned Samogitian traditional costumes, folk songs, Samogitian dances, or games.

'Toughness' is an attribute that was mentioned 8 times. Representatives of other dialects as well as Samogitian respondents used two combinations - hard character and tough character, which posed a problem. The analysis of such combinations was based on establishing whether the respondent referred to character ('toughness') or physical force ('strength'). Respondents claim that:

(35) A typical Samogitian is distinguished by a strong determined character, they are considered to be difficult to find compromise with because they extremely adhere to their beliefs' (thus 'toughness').

They also claim that:

(36) A Samogitian is a person of strong character who never backs down on an issue and tries to prove his truth and does not accept a different opinion; Samogitian is associated with a strong expressive character.

As can be seen from the examples, some view the strong Samogitianness as more negative than positive, while others view it vice versa.

The attribute 'distinction' was mentioned 7 times. This attribute embraces such words as uniqueness, individuality, distinction. These words are used in different contexts, e. g. referring to the language, character, or traditions:

(37) They speak incomprehensibly but are unique in that; Highlighting the peculiarity of the Lithuanian language; Distinct pronunciation.

Some respondents mentioned 'simplicity' (3 times), which can be considered as an opposite to distinction:

(38) Ordinary people, better than it seems at first; Maybe they are simpler, they know how to deal with troubles, do not lie, communicate more sincerely.

Analysis of the data shows that simplicity in this case is synonymous with distinction, because Samogitians stand out from the rest in their simplicity.

Other top ten attributes were not commented extensively: 'diligence' was mentioned 7 times, as well as the attribute 'cheerfulness' (with a sense of humour); 'friendliness', 'language' and 'reticence' were mentioned 6 times each.

An analysis of the attitudes of representatives of other dialects shows that their opinions quite often vary. For some, Samogitian is just one of the dialects that exist in Lithuania, with no striking differences, though most admit that they do not understand what Samogitians say, while for others it is a unique region with different customs, traditions, history and people of different character. Respondents who mentioned that they have relatives or acquaintances living in Samogitia answered in a more detailed and positive way. There were no negative answers, though there are some attributes that are not very positive: ferocity, roughness, mockery.

As it has already been mentioned, the cognitive meaning is formed when human experience is merged with knowledge, beliefs, faith and many other areas, thus the meaning of Samogitianness differs not only among separate groups (Samogitians and Aukštaitians), but also within the groups. The cognitive 
meaning of Samogitianness for Aukštaitians could be formulated as follows: Samogitianness is one of the dialects that exist in Lithuania, which most notably differs from the standard language. Representatives of this dialect are characterised by stubbornness, diligence, and economy of words.

\subsection{Comparison of the perception of Samogitianness}

The most frequently mentioned attribute by both groups is 'stubbornness' all in all, it was mentioned 120 times. It is the most prototypical attribute of Samogitianness (Figure 3).

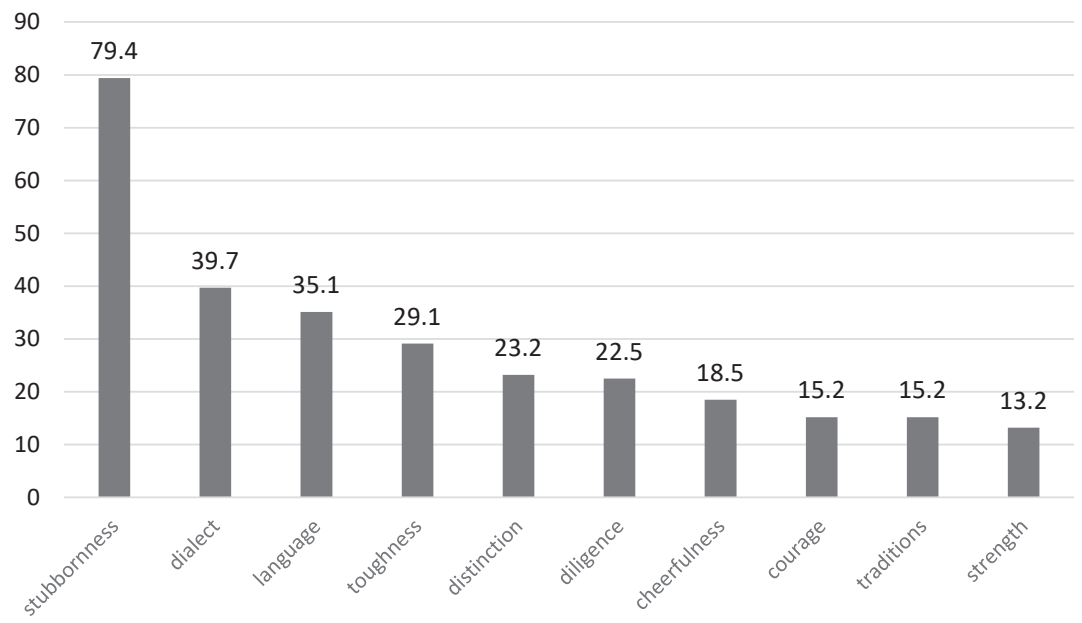

Figure 3. Attributes to describe Samogitianness as viewed by both Northern Samogitians and Aukštaitians (\%)

Both Samogitians and Aukštaitians exemplified this attribute with a saying as stubborn as a Samogitian. Samogitians refer to their stubbornness a little differently and view it as a more positive trait, but some of them claim that Samogitians maintain their position even though they know they are wrong. Respondents substantiate the attribute by claiming that Samogitians are stubborn in pursuing their goals. Representatives of other dialects who mention the attribute 'stubborn' are more likely to regard it as stubbornness that is a matter of principle and often unjustifiable. Samogitians may seem stubborn to the representatives of other dialects also because they always speak Samogitian in all situations:

(39) We do not break the jaw if someone from Aukštaitia comes.

However, there are those who think that stubbornness of Samogitians is a positive feature.

The second most frequent attribute is 'dialect', which was mentioned 60 times. Both groups claim that Samogitians are those who cherish their dialect most. Often Samogitians do not use the word 'dialect' (mentioned 33 times), but use the word 'language' (mentioned 47 times) thus emphasising that Samogitians have their own distinct language. Meanwhile, Aukštaitians used the word 'dialect' 27 times, whereas the word 'language' was used only 6 times. Samogitians are proud to speak Samogitian not only in their personal environment but also in the public domain. 
Samogitians frequently feel comfortable using Samogitian in the public domain. They think that Aukštaitians like to hear them speak in the Samogitian dialect. Most of the representatives of other dialects said that they liked the Samogitian dialect and that it was interesting to listen to it, but some members of this survey group were annoyed by the fact and found it unacceptable. Samogitians feel a kind of superiority in respect to their dialect:

(40) Nobody understands our dialect, while we, Samogitians, can understand other dialects.

Thus, the results make it clear that nationwide there is a difference in the attitudes, as Samogitians believe that they have a distinct language, whereas Aukštaitians think that it is simply one of the dialects used in Lithuania that is most distinct from the standard Lithuanian language. In total, the attribute 'dialect' was used 60 times by both groups, whereas the attribute 'language' was used 53 times.

The third most frequent attribute is 'toughness', which was mentioned 44 times. Samogitians claim that they have a strong character, stick to their opinion till the end. They emphasise that not only their character is strong, but also their men are. Aukštaitians think that the character of Samogitians is tough and expressive: (41) A person of strong character who never gives in, but tries to prove his truth at any cost and does not accept the opinion of another person (as it was mentioned, toughness is attributed to character traits, while strength is used to describe physical force).

There is a difference in the attitude to toughness, as Samogitians understand toughness of their character as pursuit of goals, whereas Aukštaitians believe that Samogitians have a strong character because they defend their opinion even if they are wrong:

(42) They are stubborn and will not back down on an issue even if they are wrong.

The analysis of the data reveals that Samogitian is important for both groups and the cognitive meaning of this concept is similar. It differs in that Samogitians tend to call their dialect a language, while Aukštaitians consider it a dialect (though many say they do not understand the Samogitian dialect). Another difference is that Samogitians express more warm emotions when talking about Samogitianness, which is obviously natural. They are often at a loss for words to describe this concept, as if it were something indescribable (e. g., some claimed that Samogitian meant their whole life). It was noticed that Aukštaitians enjoy listening to people speaking in the Samogitian dialect, while Samogitians like to be listened to. The common cognitive meaning of Samogitianness for these two groups could be as follows: Samogitianness is a dialect most distant from the standard Lithuanian language, whose representatives have their own traditions and cherish them, are stubborn, hardworking, and not talkative.

\section{Conclusions}

The research revealed that the most prototypical attribute of Samogitianness is 'stubbornness', which was mentioned by Samogitians 81 times and by representatives of other dialects - 39 times, which makes it 120 times in total. More than a half of the respondents mentioned this attribute. Both groups agree on 
the most prototypical attribute. For Samogitians the attributes of Samogitianness are 'stubbornness', 'language', 'dialect', and 'diligence', meanwhile for representatives of other dialects they are 'stubbornness', 'dialect', 'traditions', and 'diligence'. It can be argued that the prototypical meanings overlap. The attitude of Samogitians and representatives of other dialects is different towards the so-called Samogitian language, as Aukštaitians view it as a dialect and perceive Samogitia as a distinct social group. Samogitians tend to view themselves as a distinct social group with lots of distinctive features (Samogitians believe that they are Lithuanians, but feel that they are distinct from other Lithuanians), whereas representatives of other dialects see them as one of the regions of Lithuania without major differences (apart from linguistic). The attitude towards Samogitian history is also different, as Samogitians focus on their great history, while representatives of other dialects do not pay much attention to it. No major difference in the attributes provided by Samogitians and Aukštaitians was noticed, except for a more vivid emotional tone in the responses of Samogitians (e. g., my beloved land).

The cognitive survey method allowed to discover attributes, many of which would not even be thought of as belonging to the concept of Samogitian. However, if respondents were asked whether an attribute described Samogitian, many would answer positively, e.g., 'the sea' (this attribute is logically explained because Samogitians live closest to the sea). Although the purpose of this work is not to find out if Samogitian is important to Samogitians, whether they are proud of it or if they seek to promote it, the conclusion is that most Samogitians are proud of being Samogitian and strive to preserve the Samogitian dialect.

It is important to mention that the survey was filled in by a relatively small group of people, so the results of this study are not exhaustive. It cannot be said that such a small proportion of people who express their opinion reflect the attitude of the whole Lithuania towards Samogitian. For a more complete and accurate study, further analysis of lexicographic and corpora data is required.

\section{Abbreviation}

\section{DLKŽ $\check{\mathrm{e}}^{\mathrm{a}}$ Dabartinès lietuvių kalbos žodynas}

\section{References}

1. Allan, Keith. 2009. Concise encyclopedia of semantics. Boston: Elsevier Science.

2. Armstrong, Elizabeth, Ferguson, Alison. 2010. Language, meaning, context, and functional Communication. Aphasiology. 24 (4), 480-496.

3. Blair, Johnny, Conrad, Frederic, G. 2011. Sample size for cognitive interview pretesting. Public Opinion Quarterly. 75 (4), 636-658.

4. Bliumas, Remigijus. 1997. Aukštaičių ir žemaičių etnine priklausomybe determinuotų psichinių reiškinių savitumai. Psichologija. 17, 25-57.

5. Coleman, Linda, Kay, Paul. 1981. Prototype semantics: The English word lie. Language. 57, 26-44.

6. Daukantas, Simonas. 1845. Būdas senovès lietuvių kalnènu ir žemaičiu. Vanagienè, Birutè (ed.). 1993. Vilnius: Ethnos'91.

7. Fehr, Beverley, Russell, James, A. 1984. Concept of emotion viewed from a prototype perspective. Journal of Experimental Psychology: General. 113, 464-486. 
8. Fehr, Beverley, Russell, James, A. 1991. The concept of love viewed from a prototype perspective. Journal of Personality and Social Psychology. 60 (3), 425-438.

9. Forcino, Rachel C., Bustamante, Nitzy, Thompson, Rachel, Percac-Lima, Sanja, Elwyn, Glyn, Pérez-Arechaederra, Diana, Barr, Paul J. 2016. Developing and pilot testing a Spanish translation of collaborate for use in the United States. PLOS ONE. 11 (12), 1-12.

10. Harris, Catherine, L. 2003. Language and cognition. Encyclopedia of cognitive science. London: MacMillan, 1-7.

11. Ingwersen, Peter, Nielsen, Lykke, M. 1999. The word association methodology: A gateway to work-task based retrieval. Mira '99: Final Mira Conference on Information Retrieval Evaluation, 14-16 April 1999. Glasgow: Electronic workshops in computing, 17-27.

12. Kalnius. Petras. 2007a. Žemaičių etniškumas: esamas ar konstruojamas? Tautosakos darbai. 34, 15-31.

13. Kalnius, Petras. 2007b. Regioninių tapatumų judejjimo prieštaros dabartinèje Lietuvoje. Lituanistica. 3 (71), 92-112.

14. Kalnius, Petras. 2012. Žemaičiai XX a.-XXI a. pradžia. Vilnius: Mintis.

15. Keinys, Stasys (ed.). Dabartinès lietuviu kalbos žodynas. Electronic version. Vilnius: Lietuvių kalbos institutas, 2006. Available at: http://kiis.lki.lt/dabartinis

16. Kulevičius, Salvijus. 2012. Žemaičių tapatumo vingiai XXI a.: savos praeities ir paveldo paieškos. Acta humanitarica universitatis Saulensis. 14, 224-245.

17. Lysak, Hanna, Rule, Brendan, G., Dobbs, Allen, R. 1989. Conceptions of aggression: prototype or defining features? Personality and Social Psychology Bulletin. 15 (2), 233-243.

18. Manerco, Larissa et al. 2013. Concept understanding in cognitive linguistics and cognitive terminology science. Languages for Special Purposes. Multilingual, Transcultural World, Proceedings of the 19th European Symposium on Languages for Special Purposes, 8-10 July 2013, Vienna, Austria. Vienna: University of Vienna, 471-483.

19. Maumevičiené, Dainora. 2010. Prototipų teorija ir semantika. Kalbų studijos. 17, 11-18.

20. Merkytė-Švarcienė, Erika. 2016. Tarmių mentalinio žemėlapio (ne)tikslumo veiksniai: tarmès vartojimas vs. nevartojimas. Respectus Philologicus. 29 (34), 139-154.

21. Nakienè, Austè. 2007. Žemaičių savimonès paieškos internete. Tautosakos darbai. 34, 214-220.

22. Pabrèža, Juozas. 2017. Žemaičiu kalba ir rašyba. Šiauliai: Šiaulių universitetas.

23. Pajẻdienè, Jūratè. 2019. Kretingos tarmès žodyne (2011) atsiskleidžiantys žemaitiško emocinio lauko kontūrai. Acta Linguistica Lithuanica. 80, 64-104.

24. Pakalniškis, Vaidotas. 2001. Žemaitiškumas globaliame pasaulyje. Lietuvos etnologija: socialinés antropologijos ir etnologijos studijos. 1 (10), 199-216.

25. Papaurèlytè, Silvija, Župerka, Kazimieras. 2010. Lietuvos etninių sričių gyventojų charakterio bruožai kalbos pasaulèvaizdyje. Kalbos kultūra. 83, 185-201.

26. Petreikis, Tomas. 2012. Žemaitijos regioninẻ knyga ir žemaičių tapatybė XX a. I pusèje. Tautosakos darbai. 43, 85-108. 
27. Richards, Keith. 2009. Interviews. Qualitative research in applied. linguistics: a practical introduction. Heigham, Juanita, Crocker, Robert A. (eds.). Hampshire: Palgrave, 182-200.

28. Rosch, Eleanor. 1975. Cognitive representations of semantic categories. Journal of Experimental Psychology: General. 104(3), 192-233.

29. Rosch, Eleanor, Mervis Carolyn B., Gray, Wayne D., Johnson, David M., BoyesBraem, Penny. 1976. Basic objects in natural categories. Cognitive Psychology. 8, 382-439.

30. Rutkovska, Kristina, Bogdzevič, Monika. 2016. Kognitywny obraz Żmudzina w języku polskim i litewskim. Slavistica Vilnensis. 61, 107-130.

31. Smetonienè, Irena. 2015. Lietuviška garbès samprata. Parlamento studijos. 18, 63-83.

32. Uffelen, Jannique van, Heesch, Kristiann, Hill, Robert, Brown, Wendy. 2011. A qualitative study of older adults' responses to sitting-time questions: do we get the information we want? BMC Public Health. 11, 1-11.

33. Willis, Gordon, Artino, Anthony. 2013. What do our respondents think we're asking? Using cognitive interviewing to improve medical education surveys. Journal of Graduate Medical Education. 5 (3), 353-356.

34. Žemaitè. 1896. Rytą giedra. Autobiografija, apsakymai. Lietuviu literatūros lobynas XX amžius. Girdzijauskas, Vytautas (ed.). Vilnius: Lietuvos rašytojų sajunga, 2005.

\section{Kopsavilkums}

Rakstā apskatīta žemaišu jēdziena semantika un kognitīvā nozīme lietuviešu valodā. Analīzē tiek pārbaudīts, vai žemaišu jēdziena nozīme ir atkarīga no teritoriālās izplatības Žemaitijā un Aukštaitijāa Pêtījuma dati apkopoti, aizpildot anketas un ierakstot audio materiālus; ziemeļžemaiši tika aptaujāti mutiski un rakstiski. Tie, kas tika aptaujāti mutiski, runāja žemaitiski, arī dažas anketas bija aizpildītas žemaitiski. Cilvēki, kas pārstāv citus dialektus, tika aptaujāti tiešsaistes vietnē www.manoapklausa.lt. Intervējamiem tika lūgts atbildēt uz jautājumiem bez papildu domāšanas. Pētījuma datu attēlošanai izveidotas trīs atsevišķas diagrammas, kas ietver galvenos žemaišu un aukštaišu dialekta pārstāvju atribūtus. Pētījumā salīdzinātas kognitīvās nozīmes un izskaidrotas faktiskās atšķirības. Raksta galvenais mērḳis ir atklāt kognitīvās nozīmes, kas piešķirtas ziemeḷžemaišu un citu dialektu pārstāvju jēdzienam 'žemaitis', un noteikt jēdziena 'žemaitis' prototipa iezīmes. Kā liecina pētījuma rezultāti, žemaišiem žemaitiskuma atribūti ir ietiepība, valoda, dialekts un uzcītība, kamēr citu dialektu pārstāvjiem tie ir spītība, dialekts, tradīcijas un uzcītība.

Atslēgvārdi: kognitīvā semantika; kognitīvā nozīme; atribūts; prototips; žemaišu jēdziens.

\section{Appendix 1: Samogitian questionnaire}

1. Respondent's place of residence.

2. Age of the respondent.

3. Do you speak Samogitian?

4. When and where do you speak Samogitian?

5. What does the word Samogitia mean to you?

6. What is typical Samogitian in your opinion?

7. What Samogitian features would you apply to yourself?

8. What does it mean to you to be a Samogitian? 
9. How do Samogitians stand out from other dialects?

10. Do you know any sayings about Samogitians/Samogitians?

11. Is the appearance of the Samogitian different from the appearance of the representatives of other dialects?

12. What is the typical older Samogitian living in the village? (In cases when the respondent states that the Samogitian is not different from the Aukštaitian).

\section{Appendix 2: Non-Samogitian questionnaire}

1. Age of the respondent.

2. Respondent's place of residence.

3. What does the word Samogitia mean to you?

4. What is a typical Samogitian?

5. Are you interested in the Samogitian dialect?

6. How do Samogitians stand out from other dialects (in what way)?

7. Do you know any sayings about Samogitians/Samogitians?

\section{Appendix 3: Northern Samogitian data}

\begin{tabular}{|r|l|c|}
\hline No. & Attributes & Frequency \\
\hline 1 & stubbornness & 81 \\
\hline 2 & language & 47 \\
\hline 3 & toughness & 36 \\
\hline 4 & dialect & 33 \\
\hline 5 & $\begin{array}{l}\text { distinction (uniqueness, authenticity, individuality, peculiarity, } \\
\text { originality, singularity, being different) }\end{array}$ & 28 \\
\hline 6 & diligence & 27 \\
\hline 7 & courage & 21 \\
\hline 8 & cheerfulness & 21 \\
\hline 9 & slowness & 20 \\
\hline 10 & strength & 18 \\
\hline 11 & straightforwardness & 16 \\
\hline 12 & traditions (dishes, national clothes) & 15 \\
\hline 13 & customs & 14 \\
\hline 14 & rudeness & 12 \\
\hline 15 & kindness & 10 \\
\hline 16 & seriousness & 10 \\
\hline 17 & simplicity & 9 \\
\hline 18 & quietness & 9 \\
\hline 19 & own region & 9 \\
\hline 20 & motherland & 8 \\
\hline 21 & origin & 8 \\
\hline 22 & blood & 8 \\
\hline 23 & little talk (non-speaking) & 8 \\
\hline 24 & respectable & 8 \\
\hline 25 & identity & 7 \\
\hline 26 & perseverance & 7 \\
\hline 27 & friendliness & 7 \\
\hline 28 & roots & \\
\hline 29 & fast language & \\
\hline & & \\
\hline
\end{tabular}




\begin{tabular}{|c|c|c|}
\hline 30 & honourable & 6 \\
\hline 31 & reticence & 6 \\
\hline 32 & value & 6 \\
\hline 33 & generosity & 5 \\
\hline 34 & pride & 5 \\
\hline 35 & reason to brag & 5 \\
\hline 36 & life in Samogitia (Samogitia) & 5 \\
\hline 37 & lifestyle & 5 \\
\hline 38 & beauty & 5 \\
\hline 39 & patience & 5 \\
\hline 40 & nature & 5 \\
\hline 41 & belonging to the community & 5 \\
\hline 42 & ancestors & 5 \\
\hline 43 & honesty & 5 \\
\hline 44 & responsibility & 4 \\
\hline 45 & personality traits & 4 \\
\hline 46 & commitment & 4 \\
\hline 47 & culture & 4 \\
\hline 48 & home & 4 \\
\hline 49 & sincerity & 4 \\
\hline 50 & integrity & 4 \\
\hline 51 & determination & 4 \\
\hline 52 & parents & 4 \\
\hline 53 & economy & 4 \\
\hline 54 & hospitality & 4 \\
\hline 55 & folklore & 3 \\
\hline 56 & life & 3 \\
\hline 57 & strictness (appearance) & 3 \\
\hline 58 & history & 3 \\
\hline 59 & endurance & 3 \\
\hline 60 & fighting efficiency & 3 \\
\hline 61 & modesty & 3 \\
\hline 62 & help & 3 \\
\hline 63 & reliability & 3 \\
\hline 64 & patriotism & 3 \\
\hline 65 & anger & 3 \\
\hline 66 & thinness (body composition, thin chin) & 3 \\
\hline 67 & flamboyancy & 3 \\
\hline 68 & warmth & 3 \\
\hline 69 & modernity & 3 \\
\hline 70 & nationality & 3 \\
\hline 71 & fairness & 3 \\
\hline 72 & veracity & 3 \\
\hline 73 & solidarity & 3 \\
\hline 74 & height & 2 \\
\hline 75 & rural life (rurality) & 2 \\
\hline 76 & eloquence & 2 \\
\hline 77 & neighbourhood & 2 \\
\hline 78 & specificity & 2 \\
\hline
\end{tabular}




\begin{tabular}{|r|l|l|}
\hline 79 & thinking & 2 \\
\hline 80 & legacy & 2 \\
\hline 81 & advantage & 2 \\
\hline 82 & intelligence & 2 \\
\hline 83 & old fashioned character & 2 \\
\hline 84 & boor & 2 \\
\hline 85 & thrift & 2 \\
\hline 86 & native land & 2 \\
\hline 87 & silence & 2 \\
\hline 88 & reticence & 2 \\
\hline 89 & gift & 1 \\
\hline 90 & energy & 1 \\
\hline 91 & relative & 1 \\
\hline 92 & appearance & 1 \\
\hline 93 & sea & 1 \\
\hline 94 & hardness & 1 \\
\hline 95 & silent privilege & 1 \\
\hline 96 & passivity & 1 \\
\hline 97 & citizenship & 1 \\
\hline 98 & dark hair & 1 \\
\hline 99 & past & 1 \\
\hline 100 & strictness & 1 \\
\hline 101 & relic & 1 \\
\hline 102 & independence & 1 \\
\hline 103 & rudeness & 1 \\
\hline 104 & understanding & 1 \\
\hline 105 & concentration & 1 \\
\hline 106 & family & 1 \\
\hline 107 & familiarity & 1 \\
\hline 108 & speech & 1 \\
\hline 109 & peace & \\
\hline & & 1 \\
\hline
\end{tabular}

\section{Appendix 4: non-Samogitian data}

\begin{tabular}{|r|l|c|}
\hline No. & Attributes & Frequency \\
\hline 1 & stubbornness & 39 \\
\hline 2 & dialect & 27 \\
\hline 3 & traditions & 8 \\
\hline 4 & toughness & 8 \\
\hline 5 & diligence & 7 \\
\hline 6 & distinction & 7 \\
\hline 7 & cheerfulness & 7 \\
\hline 8 & friendliness & 6 \\
\hline 9 & language & 6 \\
\hline 10 & reserved & 6 \\
\hline 11 & perseverance & 5 \\
\hline 12 & lots and loud speaking & 5 \\
\hline 13 & kindness & 5 \\
\hline 14 & Samogitia & 5 \\
\hline
\end{tabular}




\begin{tabular}{|c|c|c|}
\hline 15 & rudeness & 4 \\
\hline 16 & origin & 4 \\
\hline 17 & speechlessness & 4 \\
\hline 18 & customs & 4 \\
\hline 19 & calmness & 4 \\
\hline 20 & history & 3 \\
\hline 21 & sincerity & 3 \\
\hline 22 & simplicity & 3 \\
\hline 23 & fairness & 3 \\
\hline 24 & activity & 2 \\
\hline 25 & openness & 2 \\
\hline 26 & generosity & 2 \\
\hline 27 & courage & 2 \\
\hline 28 & emotionality & 2 \\
\hline 29 & vitality & 2 \\
\hline 30 & culture & 2 \\
\hline 31 & restrained & 2 \\
\hline 32 & boor & 2 \\
\hline 33 & strength & 2 \\
\hline 34 & intelligence & 2 \\
\hline 35 & economy & 2 \\
\hline 36 & straightforwardness & 2 \\
\hline 37 & hospitality & 2 \\
\hline 38 & fierceness & 1 \\
\hline 39 & distinctiveness & 1 \\
\hline 40 & ethno cultural feature & 1 \\
\hline 41 & goodwill & 1 \\
\hline 42 & reason to brag & 1 \\
\hline 43 & lifestyle & 1 \\
\hline 44 & liveliness & 1 \\
\hline 45 & fast talking & 1 \\
\hline 46 & expressiveness & 1 \\
\hline 47 & sarcasm & 1 \\
\hline 48 & patience & 1 \\
\hline 49 & fighting efficiency & 1 \\
\hline 50 & thinking & 1 \\
\hline 51 & selflessness & 1 \\
\hline 52 & complaisance & 1 \\
\hline 53 & citizenship & 1 \\
\hline 54 & practicality & 1 \\
\hline 55 & seriousness & 1 \\
\hline 56 & honesty & 1 \\
\hline 57 & warmth & 1 \\
\hline 58 & temperamental & 1 \\
\hline 59 & enterprising & 1 \\
\hline 60 & unity & 1 \\
\hline 61 & curiosity & 1 \\
\hline
\end{tabular}

